\title{
Examining the framing patterns of environmental issues: Episodic and thematic analysis of Pakistani and British news stories
}

\author{
Atiya $\operatorname{Dar}^{1} \mid$ Shahzad Ali*2 $\mid$ Muhammad Makkey Bhutta ${ }^{2} \mid$ Mohammad Irfan Ali $^{1}$ \\ 1. Faculty of Media and Communication Studies, University of Central Punjab, Lahore, Pakistan. \\ 2. Department of Communication Studies, Bahauddin Zakariya University, Multan, Pakistan. \\ *Corresponding Author Email: shahzadmascomm@bzu.edu.pk
}

Received: September 25, 2021

Published: December 31, 2021

\begin{abstract}
Practice and applicability of environmental journalism accelerate changes in environmental policy, foster environmental awareness amongst the public and encourage environmentalism in the society. Reporting news in episodic instead of thematic manner is imperative in altering the public narrative regarding environment as well as providing assistance for significant decision making, to concerned stakeholders for better policy formation. The comparative design of this study utilized quantitative content analysis to examines framing approach of Pakistani and British environmental news stories. Using simple random sampling technique total $(n=1139)$ environmental news stories analysed from all four newspapers since 2007 to 2016-time period. The findings indicate the contrast among four newspapers of two countries (Dawn \& Nation) from Pakistani print media however (Guardian \& Telegraph) from Great Britain identify the divergent framing characteristics of Pakistani and British environmental news stories with thematic and episodic preferences. Guardian and Telegraph framed thematic news stories focusing on structural attributions while Dawn and Nation news stories evoke individualistic attributions with episodic frames. In spite of media's regular journalistic practice of featuring episodic news stories still communicators can shift their professional approach by learning the construction of persuasive thematic environmental news stories for bigger social change.
\end{abstract}

Keywords: news, media framing, thematic \& episodic news frames, environmental issues.

How to Cite: Dar, A., Ali, S., Bhutta, M. M., \& Ali, M. I. (2021). Examining the framing patterns of environmental issues: Episodic and thematic analysis of Pakistani and British news stories. Journal of Humanities, Social and Management Sciences (JHSMS), 2(2), 271-285. https://doi.org/10.47264/idea.jhsms/2.2.20

Publisher's Note: IDEA PUBLISHERS (IDEA Publications Group) stands neutral regarding jurisdictional claims in the published maps and institutional affiliations.

Copyright: (C) 2021 The Author(s), published by IDEA PUBLISHERS (IDEA Publications Group).

Licensing: This is an Open Access article published under the Creative Commons AttributionNonCommercial 4.0 International License (http://creativecommons.org/licenses/by-nc/4.0/) 
Examining the framing patterns of environmental issues: Episodic and thematic analysis ...

\section{Introduction}

The future of this planet expectedly at stake, in the year 2007 delegates from 190 countries gathered on the resort island Bali to conduct the meeting in the capacity of scientific forecast of disastrous floods and droughts, melting glaciers, unexpected deadly heat waves and disappearing of coastlines that lead towards global warming and climate change (Dawn, 2007). Although, survival of living beings depends on the nature such as water, air, food etc. Generally, material of human consumption, and every aspect of life including health, motivation, pleasure even economy directly or indirectly linked with nature. Marco Lambertini Director General WWF International (2016) in the investigative 'Living Planet Report' claimed that "for years, scientists have been alarming that human activities are directing the life towards a sixth mass destruction". An averagely $67 \%$ population of wildlife already revealed and confirmed a concerning decline by the end of this decade. Consequently, the continues environmental degradation, threaten the ecologically sustainable future of living beings. Clean environment has the status of prodigious significance at micro and macro level. According to independent analysis of (NASA) and National Oceanic and Atmospheric Administration (NOAA), the temperature of earth's surface in 2015 was the warmest since modern record keeping began in the year 1880 and this record was highest in year 1998 but changes occurred to the global surface temperature anomalies from 1880 through 2015 and the year 2015 recorded as higher than normal temperatures of the earth. However, recent global temperature conditions broken the previous records that is alarming. WWF (2016) claimed that it's been more than twenty years to Rio Earth summit and with every passing day environmental condition of the earth is getting worst. Moreover, report of Living Planet (2016) declared, most alarming situation is that many of these changes have occurred in the past decade. Climatewarming carbon emissions have increased $40 \%$ in the past 20 years, but two-thirds of that rise happened in the past decade.

According to the perspective of Beck $(1992 ; 1999)$ world risk society aims to understand the significance of media in disseminating the real-world environmental issues that are affecting the world. It has also demonstrated the reflexive modernization that subsequently responsible for economic growth and advancement in other fields of life but with parallel to this it has jeopardised its own domain of science and technology. Therefore, reflexive modernisation caused environmental hazards or destructions such as climate change, and chemical pollution etc. which are hard to control and difficult to predict their intensity through the use of technology. Moreover, environmental hazards are not limited to a particular geographical orientation rather such risks are alarming and destructive for the whole world. The notion of environment is all about the social construction of reality because of the diverse human perception related to the nature. Beck (1999) argued that environmental ideas are institutionally constructed particularly in the perspective of world risk society. Nature and its physical properties unable to shape their meanings but its concepts are socially and culturally constructed. Therefore, social actors define the environment diversely that is correlated with their ideological orientation as well as social positioning. However, scientists define environmental perspective within the domain of ecological movement which is comparatively different from the perspective of lay people. Subsequently, the conception about 'environment' and 'environmental crisis' is distant from the reality of physical world because it is manufactured in the age of modernization.

No doubt, Frames are the fundamentals of the news process. Tucker (1998) explains that frames 
are "highly ritualized symbolic structures embedded into media content". These frames are the part of media structure and content which control the flow of information to the audience. Tankard et al (1991) recognize media frame as "the central organizing idea for news content that supplies a context and suggests what the issue is through the use of selection, emphasis, exclusion and elaboration." The texts and images articulate the frame through repetition, placement and reinforcement to present a dominant interpretation, more promptly perceivable, acceptable as well as memorable than other comprehensions (Entman 1991). In short, framing constructed or structured the issues in the news stories in a particular way to make it meaningful. Tuchman (1978) narrates the process of framing by relating it with the window. Tuchman indicated:

"The view through a window depends upon whether the window is large or small, has many panes or few, whether the glass is opaque or clear, whether the window faces a street or backyard. The unfolding scene also depends upon where one stands, far or near, craning one's neck to the side, or gazing straight ahead, eyes parallel to the wall in which the window is encased."

Frames interpretation with window give us a clear description how information includes, exclude and skewed from the text in the frame and it also considerable, either that information is placed within the window metaphor or outside the view. There is probability that opinion and interpretation of author can be intervened in the framing of communication text. Moreover, Iyengar (1991) demonstrated the framing as "subtle alteration in statement or presentation of judgment in news stories". The diversification of facts and demonstration of judgments is often dependent on the decision of the reporter to maintain the reliability of sources or being biased while covering a news story (Tuchman, 1978). Consequently, political leaning of journalists affects their way of reporting the news story (Shoemaker \& Reese, 1996). On the other hand, despite of media's claim of objective or unbiased reporting still newspaper publications classified as left leaning and right leaning ideologies, these ideologies can potentially influence public perception and change the response about climate change (Leiserowitz, 2006). However, environmental issues framed differently in news media, but various research have revealed that within the journalistic domain there are certain frames which are commonly used (Dirikx \& Gelders, 2010). Therefore, such general or generic frames do not apply to explicit issues, topics, or phenomena rather these can be applied to different social situations without the limits of subject, place or time (De Vreese, 2005). Furthermore, Iyengar (1991) classified framing into two main domains episodic and thematic frames.

Maslog et al (2006) have validate the news framing as a "process of organizing a news story thematically, stylistically and factually to convey a specific story line". Mostly acknowledged research classified the frames into different categories in order to understand framing trends in environmental reporting. However, Wise and Brewer (2010) studied the frame classification in their research and concluded that partisan frames used to manipulate the social situations in favour of beneficial stakeholders who sponsored to construct such frames and consequently presupposed policy alter the public opinion. Moreover, several other frames used in news content such as episodic, thematic, game and strategy frames generally applied for political manipulation. Fundamental classification of news frames elaborated as episodic and thematic. Accordingly, episodic frames are event oriented and focused on the contemporary happenings without detailed background information. Although, thematic frames are abstract in nature to promote contextual information putting emphasis on solution and effects of the issue (Iyennger, 
1991). Apart from the framing of environmental news stories it is also important to understand the rationale behind the selection of Pakistani and British newspapers for the comparative analysis of environmental news stories. As, eleventh edition of the analysis of (Global Climate Risk Index, 2016) reconfirms that, less developed countries are generally more vulnerable by the environmental degradation than industrialized countries. Although, climate change tendency is being increasing due to greenhouse gases (GHGs) in the atmosphere, the use of fossil fuels, and other human activities caused major worldwide concern for GHGs. Particularly, Pakistan's climate change condition is posing a direct threat to its water, food, and energy security because Pakistan's vulnerable situation is increasing the adverse consequences and will be more harmful in the future. As the average global temperature, which increased by $0.6{ }^{\circ} \mathrm{C}$ over the past century, is projected to increase further by 1.1 to $6.4{ }^{\circ} \mathrm{C}$ by the end of the current century. Already Pakistan is rated as a "high risk" country in the global rankings for climate change. According to Change Vulnerability Index (2016) Pakistan as a developing country is being ranked 29 with high risk whereas United Kingdom on rank of 155 with lowrisk climate change vulnerability. It's thought provoking to compare the developing and developed countries framing practices on environmental concerns while Pakistan and Britain fall in the list of WWF worldwide network of environment. This study has built on the following objectives.

\subsection{Objectives}

- To examine the framing patterns of environmental issues in Pakistani and British news stories.

- To investigate the prevalence of thematic versus episodic frames in news coverage of Pakistani and British news stories.

\subsection{Hypotheses}

- HI: It is more likely the framing patterns of Guardian and Telegraph are different on the preferences with comparison to Dawn and Nation while reporting of environmental news stories.

- HII: It is more likely news stories in British print media dominating with thematic frames while news stories in Pakistani print media focuses on episodic frames in the reporting of environmental issues.

\section{Literature review}

\subsection{Thematic versus episodic frames}

This research has adopted framing analysis procedure by following the work of (Domfeh, 1999; Obeng-Quaidoo, 1985; Iyengar \& Kinder, 1987; Pratt et al., 2002; Sanders, 2000; Smith \& Wakefield, 2005; Valeda, 2002; Verdoolaege, 2005) to understand how Pakistani and British print media represent the environmental issues in framing domain. Framing analysis is an important concept because the way media represent the issues in news narrative can potentially influence the audiences' perception about the social phenomena therefore identification of journalistic patterns can bring new insights to aware the masses in more influential way (Valeda, 2002). Fundamentally, frames perform four functions to answer the implied questions in the news stories through diagnosing the problem, identification of cause, postulating the 
judgement, and mitigating solution to the problem are the procedures to define the context of frames in mass media and involve the masses in social issues (Tuchman, 1978).

However, numerous studies of Iyengar (1990, 1991, and 1996) divided the news stories into two major frames known as thematic and episodic. For example, Iyengar conducted a study on the coverage of domestic poverty in America and classified the relevant issue into two categories, in the first category he describes the domestic poverty within the context of social outcome (thematic frame), whereas on the other hand the same issue manipulated in the context of individual victims (Episodic frame). Moreover, episodic frames highlighted the issues on individual sufferings such as the occurrences of illegal migrants, group suicide, and homeless persons are few examples of it. Although, thematic frames focused on the issues or occurrences in some general and broader context. Therefore, thematic frames, portray the political issues in broad and abstract spectrum within historical and societal context (Park, 2012). Furthermore, thematic news story on corruption might highlight the contemporary trends, corruption rate and the factors behind the frequent escalation. Usually, thematic frames focused on the background coverage of a specific issue. However, episodic news reports include sensational, vivid or provocative images of the story and reporters don't bother to interpret the issues. Several content analytic studies including the studies of (Gamson, 1989; Altheide, 1987) attempted to document the presence of episodic frames in news coverage. Furthermore, thematic and episodic news frames can be elaborated with this example. For instance, if a news story with episodic frame cover the corruption case of PANAMA issue in Pakistan, main focus of this story would be the personal sufferings, allegation and court hearings of Sharif family, whereas, thematic frame will focus on the corruption rate, globalized occurrences of corruption in the world, or matter of public policy debate such as institutions propositions to reduce political corruption, and anti-corruption initiatives. News stories with thematic frames consist of impersonal, abstract and background information. By contrast, episodic frames cover the issue from personal experience or viewpoint. Moreover, a comparative framing analysis of terrorism opted a mix method approach and concluded that U.S print media engaged in more episodic frames whereas UK print media focus on the thematic coverage of terrorism (Papacharissi \& Oliveria, 2008). Overall impression of U.S press dominating with military approach while U.K newspapers inclined towards diplomatic assessment of terrorism events.

Generally, thematic and episodic both frames contribute a different influential power on its user's perception. However, "thematic news stories focusing on structural attributions, news stories with episodic frames evoke individualistic attributions" (Iyengar, 1990). The news framing of issues has a significant influence on audience understanding of cultural, social and political realities (Gamson, 1992). A number of recent studies have found that framing of climate change is episodic in nature (Boykoff \& Boykoff, 2007; Check, 1995; Hutchison, 2008; Nitz \& Ihlen, 2006; von Storch \& Krauss, 2005). However, thematic and episodic coverage of news stories are significantly different in nature. Considering the complex nature of environmental issues, often episodic coverage does not provide the comprehensive picture of the issue (Boykoff \& Boykoff, 2007). With the relevance of environmental issues, it causes problem to the consistency and context. Media have given more coverage to certain events in episodic frames, including Al Gore's documentary 'An Inconvenient Truth' and Twelfth Conference of the Parties to the United Nations Framework Convention on Climate Change. While episodic frames found dominant in the coverage of politics on European television within past 24 hours (Semetko \& Valkenburg, 2000). Episodic coverage of news stories lacks in the interpretation and providing context to the event (Check, 1995). Moreover, news stories 
Examining the framing patterns of environmental issues: Episodic and thematic analysis ...

with episodic frames remain unreported for long period of time, until another event happen to bring it to the media (Nisbet \& Lewenstein, 2002). Contextual information is mandatory in order to understand the environmental issues. So, Corbett \& Durfee (2004) explored that news stories of climate change get more certainty if presented with context. In reverse episodic frames don't have the potential to communicate the entire story to the audience. Iyengar (1991) figure out that episodic coverage might be one of the reason Americans could not observe the interconnection among several issues on the media. The vulnerability of episodic framing is that it may not include many issues of significance in the news coverage this is why citizens unable to observe the national affairs critically. Devin et al. (2012) shed light on another perspective that liberal newspaper presented climate change with thematic frames as compared to conservative. So political leaning is also a contributing factor in the selection of thematic or episodic frames. Since 1980s, researchers have substantially invested the energy to studying the forces of agenda setting and framing. Multiple studies concluded that media doesn't only set the agenda for public, but it has the capability to indicate how individuals will analyse the issues (Entman 1989; Iyengar 1991; Eichhorn 1993 cited in Dearing \& Rogers 1996). Moreover, previous research portrayed a global perspective of news framing in the sphere of thematic and episodic frames, while the purpose of this study is to explore journalistic choices of Pakistani and British print media to cover the news stories of environmental issues either by using episodic or thematic frames.

\section{Research methodology}

In order to address the hypotheses and explored the answers of this study a quantitative content analysis technique to newspaper coverage of environmental news stories was employed. This comparative research design with deductive approach examined the framing patterns of environmental issues in episodic and thematic analysis of Pakistani and British news stories. Patton (2002) argued that quantitative research design employed standardized measures so that diverse perspectives of content to be recorded into classified predetermined response categories that are assigned with numerals. He elaborates the primary advantage of quantitative research design in such a manner that, it has the potential to record the large amount of elements into more confined set of questions in order to statistically aggregate and compare the data. Selected newspapers from both countries offer a broad range of perspectives on Pakistani and British journalism therefore those publications are logically selected for the analysis. The Telegraph and the Guardian are internationally famed British elite newspapers because of their prestigious status among the world's top publications therefore those publications have considered as the representatives of British media (National Dailies, 2018). The daily Dawn and the Nation are among the elite newspapers of Pakistan with high rank of circulation in print media market (Ricchiardi, 2012).

Assuredly, all four newspapers have a profound effect on the environmental opinion as well as policy making process. However, secondary data of news stories was gathered through Lexis/Nexis academic search engine by searching the keywords such as environmental issues, environment, climate change, global warming, deforestation, pollution, natural disasters, and wildlife. However, news stories were identified and selected on the basis of the relevance with above mentioned keywords and eliminated due to irrelevance with the subject. To qualify the sample each news story must contain the keyword "environmental issues" at least not less than three times also first and last paragraph of the news story address the environment as a primary theme. Timeframe from $1^{\text {st }}$ January 2007 to $31^{\text {st }}$ December 2016 was selected for analysis and 
this period has been very crucial with regard to climatic changes, rising surface temperature, increasing smog and many other unneglectable environmental hazards occurred in past ten years. Such as, "climate-warming carbon emissions have increased $40 \%$ in the past 20 years, but two-thirds of that rise occurred in the past decade (WWF, 2015). Simple random sampling technique employed to draw the appropriate sample of this study. Within the simple random sampling, every unit of the population has an equal chance of selection in the sample (Bellhouse, 2005). The below mention sampling fraction illustrated that ' $n$ ' value denotes to the sample size and ' $\mathrm{N}$ ' value refers to the population size.

Table 1: Sample

\begin{tabular}{|c|c|c|}
\hline $\begin{array}{c}\text { Publication } \\
10 \text { years' environmental } \\
\text { news coverage }\end{array}$ & $\begin{array}{c}N \text { value } \\
\text { total number of news stories }\end{array}$ & $\begin{array}{c}n \text { value } \\
\text { sample size }\end{array}$ \\
\hline Dawn & 1353 & 302 \\
\hline Nation & 1158 & 291 \\
\hline Telegraph & 1100 & 233 \\
\hline Guardian & 1704 & 313 \\
\hline
\end{tabular}

\subsection{Depth of coverage}

Environmental reporting of Pakistani and British newspapers determined by exploring the dominance of thematic or episodic frames in the relevant selected news stories. Whereas thematically or episodically richness of environmental news stories of Pakistani and British print media measured through its presence or absence in the reporting. Following mentioned are the operational definitions of the concerned theoretical terms.

\subsubsection{Thematic frames}

News stories that are abstract in nature focus on the effects and solutions and also include contextual and background information (Iyengar, 1991).

\subsubsection{Episodic frames}

News stories that are more event oriented in style and focused on the current happening despite of giving a contextual or background information of the happening (Iyengar, 1991).

Contrast of episodic frames with thematic frames

\begin{tabular}{|l|l|}
\hline Episodic Frame & Thematic Frame \\
\hline Focus on an individual & Focus on the issue \\
\hline Focus on the single event & Focus on trends over time \\
\hline On the private realm & $\begin{array}{l}\text { Public (the surrounding environment, public } \\
\text { situations). }\end{array}$ \\
\hline Fix the person experiencing a problem & Fix the conditions that led to the problem \\
\hline Better information & Better policies \\
\hline $\begin{array}{l}\text { Event oriented and focused on the } \\
\text { current happening }\end{array}$ & Abstract in nature, contextual and solution oriented \\
\hline
\end{tabular}


Examining the framing patterns of environmental issues: Episodic and thematic analysis ...

Environmental news stories were considered as unit of analysis. Each and every unit was coded to analyse the name of publication and prominent frames (thematic vs episodic) in the news reporting were measured.

\subsection{Pre-test}

Randomly three news stories of each year from all four newspapers including the Guardian, the Telegraph, Dawn and the Nation were selected for a pre-test purpose and tested the coding scheme of the study, it helped researcher to improve the coding process. Total number of one hundred twenty (120) news stories were analysed in this process.

\subsection{Measurement and reliability}

Measurement of news framing (thematic and episodic) was developed based on a theoretical review of environmental coverage in the sample. Thematic frames indicate the framing that highlight an issue in a larger and more abstract social context. The central idea of thematic framing is to provide contextual and big-picture information. This framing approach may use historical data, statistics, and expert interviews. However, episodic framing implicates storytelling in which an issue is presented the current happening by means of a specific event or case and its primary focus is on telling individual stories, reporting circumstantial events or disasters. This framing approach may use typical storytelling techniques such as covering, meetings, summits, resolutions, conflicts, disasters. Episodic environmental news stories serve the purpose of encouraging cognitive information processing of readers whereas thematic news framing of environment motivates audience analytical approach. News framing was measured on the scale of present and absent. Framing was measured on three parameters such as:

a) Thematic framing only (present thematic frame)

b) Combination of episodic and thematic with an emphasis on thematic framing (present thematic frame)

c) Episodic framing only (present episodic frame)

d) Combination of episodic and thematic with an emphasis on episodic framing (present episodic frame).

A news story would have thematic or episodic in nature, presence of one frame means the absence of other frame, both frames cannot be present at the same time in a story. The relative weight of episodic vs. thematic framing, when both were identified in a news item was determined based on the length (space) of the use of each framing as well as the holistic (overall) impression that the news item left on the reader.

There are several methods to calculate the reliability coefficient but the simplest way to measure inter-coder reliability is Holsti's method (1969) in which two coders code the same units that is equal to percentage of agreement.

The formula is given below:

$$
\mathrm{PA}_{o}=2 \mathrm{~A} /\left(n_{A}+n_{B}\right)
$$

Total number of news stories from all four newspapers were 1139, for the purpose of intercoder reliability only $10 \%$ of whole sample $(\mathrm{N}=56)$ for each coder was selected. As previous 
researchers (Benoit, et. al, 2007; Kaid \& Wadsworth, 1989; Lacy \& Riffe, 1996; Neuendorf, 2002; Wimmer \& Dominick, 2006) suggested the $10 \%$ of total sample is an appropriate ratio to test the inter-coder reliability. Depth of news coverage in terms of thematic and episodic news framing $(.88 \%)$ level of agreement found between coder one and coder two.

\section{Results and analysis}

Table 1(a) is about the observations of thematic frame dominance in the coverage of Pakistani and British print media related to environmental news stories. Frequencies of the table shows the comparative analysis of Pakistani and British elite press regarding thematic frame coverage and findings revealed that British print media more inclined towards thematic news framing such as $(77.9 \%)$ news stories constructed with thematic frames and only (21.5\%) thematic news coverage of environmental news stories appears absent. However, thematic news frames do not appear on the agenda of Pakistani print media therefore $(22.1 \%)$ news stories cover thematic frame while an immense portion of environmental news stories not constructed them in thematic frames such as frequency of absent frames included as $(78.5 \%)$.

Table 1(a): Depth of News Coverage: Cross Tabulation Thematic Frames

\begin{tabular}{lcccc}
\hline & & \multicolumn{2}{c}{ Newspaper } & \multirow{2}{*}{ Total } \\
\cline { 3 - 4 } & & Pakistani & British & \\
\hline \multirow{3}{*}{ Thematic } & \multirow{2}{*}{ Absent } & 475 & 130 & 605 \\
& & $78.5 \%$ & $21.5 \%$ & $100.0 \%$ \\
& Present & 118 & 416 & 534 \\
& & $22.1 \%$ & $77.9 \%$ & $100.0 \%$ \\
\multirow{2}{*}{ Total } & & 593 & 546 & 1139 \\
\hline
\end{tabular}

the Chi-square test of independence evident of a statistically significant difference between Pakistani and British newspapers with respect to their viewpoint as $\chi 2(2)=361.712$, value of continuity correction is 359.455 , likelihood ratio 383.380 , and the count of linear by linear is $361.394, p=.000$ is less than 0.05 . However, findings of this test recommended that thematic news frames dominating in the environmental news coverage of British print media as compared to Pakistani elite newspapers. Therefore, first hypothesis of this study has been approved.

Table 1(b): Chi-Square Tests

\begin{tabular}{|c|c|c|c|c|c|}
\hline & Value & df & $\begin{array}{c}\text { Asymptotic Significance } \\
\text { (2-sided) }\end{array}$ & $\begin{array}{l}\text { Exact Sig. } \\
(2 \text {-sided })\end{array}$ & $\begin{array}{r}\begin{array}{r}\text { Exact Sig } \\
\text { (1-sided) }\end{array} \\
\end{array}$ \\
\hline Pearson Chi-Square & $361.712^{\mathrm{a}}$ & 1 & .000 & & \\
\hline Continuity Correction ${ }^{\mathrm{b}}$ & 359.455 & 1 & .000 & & \\
\hline Likelihood Ratio & 383.380 & 1 & .000 & & \\
\hline Fisher's Exact Test & & & & .000 & .000 \\
\hline Linear-by-Linear Association & 361.394 & 1 & .000 & & \\
\hline $\mathrm{N}$ of Valid Cases & 1139 & & & & \\
\hline
\end{tabular}

a. 0 cells $(0.0 \%)$ have expected count less than 5 . The minimum expected count is 255.98 .

a. Computed only for a $2 \times 2$ table 
Examining the framing patterns of environmental issues: Episodic and thematic analysis ...

Table 2(a) demonstrate the presence of episodic frames in the environmental news coverage of Pakistani and British elite newspapers. Observations revealed that Pakistani print media focused $(78.5 \%)$ environmental news stories constructed in episodic frames however only (22.1\%) episodic frames absent in the construction of environmental news stories. Contradictory, British print media cover only $(21.5 \%)$ environmental news stories in episodic frames while major portion of news stories (77.9\%) absent episodic frame.

Table 2(a) Depth of News Coverage: Cross Tabulation Episodic Frames

\begin{tabular}{lcccc}
\hline & & \multicolumn{2}{c}{ Newspaper } & \multirow{2}{*}{ Total } \\
\cline { 3 - 4 } & \multirow{2}{*}{ Absent } & Pakistani & British & \\
\hline \multirow{3}{*}{ Episodic } & & 118 & 416 & 534 \\
& & $22.1 \%$ & $77.9 \%$ & $100.0 \%$ \\
& Present & 475 & 130 & 605 \\
& & $78.5 \%$ & $21.5 \%$ & $100.0 \%$ \\
Total & & 593 & 546 & 1139 \\
\hline
\end{tabular}

Overall, results of this table indicate that chi-square test of independence measure the significant difference between British and Pakistani newspapers with respect to their viewpoint as $\chi^{2}(2)=361.712, p=0.000$ is less than 0.05 , value of likelihood ratio is $383.380<0.05$, continuity correction is $359.455<0.05$, linear by linear presented as $361.394<0.05$. Findings of this table concluded that British print media much focused on thematic news frames in order to construct environmental news stories while Pakistani print media more inclined towards episodic news frames while framing the environmental news stories.

Table 2(b): Chi-Square Tests

\begin{tabular}{|c|c|c|c|c|c|}
\hline & Value & df & $\begin{array}{c}\text { Asymptotic Significance } \\
(2 \text {-sided })\end{array}$ & $\begin{array}{l}\text { Exact Sig. } \\
(2 \text {-sided })\end{array}$ & $\begin{array}{r}\text { Exact Sig. } \\
(1 \text {-sided })\end{array}$ \\
\hline Pearson Chi-Square & $361.712^{\mathrm{a}}$ & 1 & .000 & & \\
\hline Continuity Correction $^{\mathrm{b}}$ & 359.455 & 1 & .000 & & \\
\hline Likelihood Ratio & 383.380 & 1 & .000 & & \\
\hline Fisher's Exact Test & & & & .000 & .000 \\
\hline Linear-by-Linear Association & 361.394 & 1 & .000 & & \\
\hline $\mathrm{N}$ of Valid Cases & 1139 & & & & \\
\hline
\end{tabular}

a. 0 cells $(0.0 \%)$ have expected count less than 5. The minimum expected count is 255.98 .

b. Computed only for a $2 \times 2$ table

\section{Discussion and findings}

This study particularly examined whether the coverage of environmental issues in Pakistani and British print media covered episodically or thematically under the structural frame approach. Subsequently, back in the result chapter mentioned in table (1) shown that a major portion of total stories seventy-seven point nine (77.9\%) constructed under thematic news frame in British print media (the Guardian and the Telegraph) and comparatively lower tendency of Pakistani print media (Dawn and the Nation) towards thematic framing of environmental issues can be observed therefore a small portion of twenty-two point one 
(22.1\%) frequency values are the depiction of Pakistani print media prevalence on thematic frames. Furthermore, Pakistani print media including Dawn and the Nation framed seventyeight-point five $(78.5 \%)$ environmental news stories in episodic frame with an overwhelmed majority of responses but in comparison, only twenty-one-point five (21.5\%) news stories constructed under episodic frames in British print media such as in the Guardian and the Telegraph. Consequently, hypotheses of this study have approved and reflects that an overwhelmed majority of British print media frame environmental issues in thematic however contrarily Pakistani print media frame environmental news stories in episodic manner. Both thematic and episodic frames hold different influential power on the perception of its users by reporting the related issue on the media. However, thematic news stories of British print media provoke more structural attributions, but episodic stories of Pakistani print media evoke individualistic attributes (Iyengar, 1990). News story, frame in a particular manner lead towards the significant influence on the public perception that help to shape the cultural, social and political realities in their heads (Gamson, 1992). Significant findings of the hypotheses revealed that the number of thematic news stories in British print media about environmental issues is a considerable phenomenon, while Pakistani elite newspapers do not typically engage in meaningful environmental debate. However, Pakistani print media intend to employ episodic frames that caused to ignore the broader context in which environmental issues occurred, and also obscure the links between individual environmental issue as well as the context of occurrence. Their episodic news frames do not reflect the fundamental reasons of environmental issues. Therefore, such kind of environmental coverage would be less interesting for the public because of several factors such as deficiency to report background information, consequences and solution of the environmental issues.

Although, previous research (Check, 1995; von Storch \& Krauss, 2005; Nitz \& Ihlen, 2006; Boykoff \& Boykoff, 2007; Hutchison, 2008; ) have examined that majority of climate change news coverage report the issue in episodic frame. Similarly, findings of this portion of research supports the argument of (Boykoff, 2007; Boykoff \& Boykoff, 2007b) who argued that often episodic frame doesn't "provide the complete picture of the story and creates a problem of consistency and context". Boykoff (2007) examined that in American media "dramatic events involving international personalities favour episodic (rather than thematic) framing". While Park (2012) concluded that news stories should be preferably consists of thematic structural approach instead of episodic. Similarly, Hart (2011) argued that thematic frames of environmental issues with comparison to episodic frames considerably more effective for individual behaviour and mitigate environmental support policies. Significance of thematic news frame in British print media highly endorsed the findings of above-mentioned studies. Therefore, findings of British print media claimed in suggestive manner that thematic frames "tend to promote a sense of social or institutional responsibility" although episodic frames in Pakistani print media "place responsibility on individual" (Iyengar, 1991). However, types of frames in Pakistani and British print media represent prime social values differently, and simultaneously construct salience of the matter and also endorse a specific policy direction (Sniderman, Brody \& Tetlock, 1991).

\section{Conclusion}

Division of environmental issues into thematic and episodic media framing contribute to understanding effective environmental communication. Furthermore, among the utmost substantial findings, Pakistani newspapers portray a narrower extent of coverage with 
Examining the framing patterns of environmental issues: Episodic and thematic analysis ...

episodically dominating news stories which majorly focus on the reporting of environmental disasters, but on the other hand British print media present greater range of coverage with thematically advanced news stories better interrelated with environmental issues to the dominions of politics, economy, and culture. As its worth mentioning thematic frames in the news stories of British print media predominant over the episodic frame news stories of Pakistani print media and potentially it can influence the way people understand the environmental concerns and responsibility. Specific measures are necessarily required to overcome the dominance of episodic frames in environmental news coverage of Pakistani print media such as "restoration of watchdog journalism and reinforcement of professional standards of journalists" to make the news media better contributor in pro environmental debates. Media preference of Pakistani elite newspapers telling the news stories in episodic instead of the importance of this distinction is that the two types of frames have different effects on how people view a given problem; and whether people will see the need for individual-level and/or broader social or institutional solutions to that problem.

\section{References}

Altheide, D. L. (1987). Format and symbol in television coverage of terrorism in the United States and Great Britain. International Studies Quarterly, 31(2), 161-176. https://doi.org/10.2307/2600451

Bellhouse, D. R. (2000). De Vetula: a medieval manuscript containing probability calculations. International Statistical Review, 68(2), 123136. https://doi.org/10.1111/j.1751-5823.2000.tb00317.x

Boykoff, M. T. \& Boykoff, J. M. (2007). Climate change and journalistic norms: A case-study of US mass-media coverage. Geoforum, 38 (6), 1190-1204. https://doi.org/10.1016/j.geoforum.2007.01.008

Boykoff, M. T. (2007b). From convergence to contention: United States mass media representations of anthropogenic climate change science. Transactions of the Institute of British Geographers, 32(4), 477-489. https://doi.org/10.1111/j.14755661.2007.00270.x

Check, T. (1995). The evaluation of scientific evidence on the Exxon Valdez oil spill, presented at Conference Proceedings-National Communication Association/American Forensic Association (Alta Conference on Argumentation, (397-402). https://nrt.org/sites/2/files/Valdez\%20spill\%20RTP.pdf

Corbett, J. B., \& Durfee, J. L. (2004). Testing Public (Un)Certainty of Science: Media Representations of Global Warming. Science Communication, 26(2), 129-151. https://doi.org/10.1177/1075547004270234

De Vreese. (2005). News framing: theory and typology. Information Design journal, 13(1), 51-62. https://asset-pdf.scinapse.io/prod/2089363775/2089363775.pdf

Dearing, J. W. \& Rogers, E. M. (1996). Communication Concepts: Agenda-Setting. Sage. https://doi.org/10.1111/j.1460-2466.2006.00005.x

Domfeh, K. A. (1999). Evaluation of environmental news coverage in Ghana. Journal of Environmental Health, 62(3), 27-

32. https://doi.org/10.1080/01296612.2021.1997526

Dirikx, A., \& Gelders, D. (2010). To frame is to explain: A deductive frame-analysis of Dutch and French climate change coverage during the annual UN Conferences of the 
Parties. Public Understanding of Science, 19(6), 732-742. https://doi.org/10.1177/0963662509352044

Entman, R. (1989). Democracy without Citizens: Media and the Decay of American Politics. Oxford University. https://doi.org/10.1080/08821127.1991.10731345

Entman, R. (1991). Framing US coverage of international news: contrasts in the narratives of the KAL and Iran Air incidents. Journal of Communication, 41(4), 627. https://doi.org/10.1111/j.1460-2466.1991.tb02328.x

Fahmy, S. \& Kim, D. (2008). Picturing the Iraq War: Constructing the Image of War in the British and U.S. Press. International Communication Gazette, 70(6), 443-462. https://doi.org/10.1177/1748048508096142

Gamson, W., \& Modgliani, A. (1989). Media discourse and public opinion on nuclear power: A constructionist approach. American Journal of Sociology, 95(1), 1-37. https://www.jstor.org/stable/2780405

Gamson, W. A. (1992). Talking Politics. Cambridge University. https://assets.cambridge.org/97805214/30623/sample/9780521430623ws.pdf

Hallin, D.C., \& Mancini, P. (2004). Comparing media systems: Three models of media and politics. Cambridge University. https://doi.org/10.1017/CBO9780511790867

Hart, Philip S. (2011). One or Many? The Influence of Episodic and Thematic Climate Change Frames on Policy Preferences and Individual Behavior Change. Science Communication, 33, 28-5. https://doi.org/10.1177/1075547010366400

Hutchison, P. J. (2008). Journalism and the perfect heat wave: Assessing the reportage of North America's worst heat wave, July-August 1936. American Journalism, 25(1), 31-54. https://doi.org/10.1080/08821127.2008.10678091

Iyengar, S. (1991). Is Anyone Responsible? Now Television Frames Political Issues. University of Chicago. https://doi.org/10.7208/chicago/9780226388533.001.0001

Iyengar, S., \& Kinder, D. R. (1987). News that matters: Television and American opinion. The University of Chicago. https://politicalscience.stanford.edu/publications/newsmatters-television-and-american-opinion

Iyengar, S. (1990). Framing responsibility for political issues: The case of poverty. Political Behaviour, 12(1), 19-40. https://link.springer.com/article/10.1007/BF00992330

Iyengar, S. (1996). Framing responsibility for political issues. Annals of the American Academy of Political and Social Science, (546), 59-70. https://doi.org/10.1177/0002716296546001006

Leiserowitz, A. A. (2006). Climate change risk perception and policy preferences: The role of affect, imagery, and values. Climatic Change, (77), 45-72. https://climatecommunication.yale.edu/wp-

content/uploads/2016/02/2006_01_Climate-Change-Risk-Perception-and-PolicyPreferences.pdf

Maslog, C. C., Lee, \& Kim. (2006). Framing Analysis of a Conflict: How Newspapers in Five Asian Countries Covered the Iraq War. Asian Journal of Communication, 16(1),1939. https://doi.org/10.1080/01292980500118516

Nisbet, M. C., \& Lewenstein, B. V. (2002). Biotechnology and the American Media: The Policy Process and the Elite Press, 1970 to 1999. Science Communication, 23(4), 359-391. https://hdl.handle.net/1813/14239

Nitz, Michael, Ihlen, \& Oyvind (2006). Oil and gas as natural riches or environmental problems: Framing contests in public relations. Conference Papers presented at International

Communication Association. 
Examining the framing patterns of environmental issues: Episodic and thematic analysis ...

https://doi.org/10.1080/15531180701623478

Obeng-Quaidoo, I. (1985). "Media habits of Ghanaian youth". In F. O. Ugboajah (Ed.), Mass communication, culture and society in West Africa (pp. 237-249). Hans Zell Publishers. https://doi.org/10.7176/RHSS

Park, S. C. (2012). How the media frame political corruption: episodic and thematic frame stories found in Illinois newspapers (published master's thesis). Southern Illinois University Carbondale Chicago. https://paulsimoninstitute.siu.edu/_common/documents/whats-in-the-water/waterillinois/park.pdf

Patton, M. Q., \& Patton, M. Q. (2002). Qualitative research and evaluation methods. Sage. https://www.proquest.com/openview/e31279614abc4b0713cb979102be86a6/1?pqorigsite $=$ gscholar $\&$ cbl $=32387$

Pratt, C. B., Ha, L., \& Pratt, C. A. (2002). Setting the public health agenda on major diseases in sub-Saharan Africa: African popular magazines and medical journals, 1981-1997. Journal of Communication, 52(4), 889-904.

Papacharissi., Z. \& de Fatima Oliveira M. (2008). News Frames Terrorism: A Comparative Analysis of Frames Employed in Terrorism Coverage in U.S. and U.K. Newspapers. The International Journal of Press/Politics, 13(1), 52-74. https://doi.org/10.1177/1940161207312676

Ricchiardi, S. (2012). Challenges for Independent News Media in Pakistan. A report to the Centre for International Media Assistance. https://reliefweb.int/report/pakistan/challenges-independent-news-media-pakistan

Semetko, H. A., \& Valkenburg, P. M. (2000). Framing European politics: A content analysis of press and television news. Journal of Communication, 50(2), 93-110. https://www.academia.edu/7703226/Framing_European_politics_A_content_analys is_of_press_and television_news

Sniderman, P. M., Brody, R. A. \& Tetlock, P. E. (1991). Reasoning and Choice: Explorations in Political Psychology. Cambridge University. https://doi.org/10.1017/CBO9780511720468

Smith, K. C., \& Wakefield, M. (2005). Textual analysis of tobacco editorials: how are key media gatekeepers framing the issues. American Journal of Health Promotion, 19(5), 361-368. https://doi.org/10.4278/0890-1171-19.5.361

Shoemaker, P. J., \& Reese, S. D. (1996). Mediating the message: Theories of influences on mass media content. Longman. http://chinhnghia.com/mediating-the-message.pdf

Sanders, J. (2000). South Africa and the international media, 1972-1979: A struggle for representation. Frank Cass. https://eprints.soas.ac.uk/28509/1/10672668.pdf

Tankard. W., Hendrickson, L., Silberman, J., Bliss, K., \& Ghanem, S. (1991). Media frames: Approaches to conceptualization and measurement. Paper presented at the Association for Education in Journalism and Mass Communication. https://doi.org/10.1177/0016549205056054

Tuchman, G. (1978). Making news: A study in the construction of reality. The Free. https://doi.org/10.1177/073088848000700406

Tucker, L. R. (1998). The framing of Calvin Klein: A frame analysis of media and discourse about the august 1995 Calvin Klein jeans advertising campaign. Critical Studies in Mass Communication, 15(2), 141. https://doi.org/10.1080/15295039809367039

Tuchman, G. (1978). Making news: A study in the construction of reality. The Free. https://doi.org/10.1177/073088848000700406

Tran, L. S. (2014). Environmental Journalism: A Case Study of the Canadian Bituminous 
Sands (Published Master's thesis). Concordia University, Montreal Quebec Canada. https://spectrum.library.concordia.ca/id/eprint/978182/4/Tran_MA_S2014.pdf

Valeda, M. E. P. (2002). Gender frame and news frame: Local newspaper coverage of the 1999 Indianapolis mayoral election (unpublished doctoral dissertation). Ohio University, Athens. $\quad$ https://paulsimoninstitute.siu.edu/_common/documents/whats-in-thewater/water-illinois/park.pdf

Verdoolaege, A. (2005). Media representations of the South African Truth and Reconciliation Commission and their commitments to reconciliation. Journal of African Studies, 17(2), 181-189. https://www.jstor.org/stable/4141309

von Storch, H. \& Krauss, W. (2005). Culture contributes to perceptions of climate change. Nieman Reports, 59(4), 99-102. https://nieman.harvard.edu/articles/culturecontributes-to-perceptions-of-climate-change/

Wise, D., \& Brewer, P. R. (2010). Competing Frames for a Public health issue and their effects on public opinion. Mass Communication and Society, 13(4), 435-457. https://doi.org/10.1080/15205430903296077 